\author{
Krzysztof FALKOWSKI ${ }^{1}$ \\ Krzysztof SIBILSKI ${ }^{2}$
}

\title{
ZAWIESZENIA MAGNETYCZNE W SYSTEMIE STARTU I LĄDOWANIA - PROJEKT GABRIEL
}

\begin{abstract}
W pracy przedstawiono koncepcję systemu startu i lądowania wykorzystującą układ zawieszeń magnetycznych. Ze względu na bardzo dobre właściwości funkcjonalne zawieszeń magnetycznych, np. praca w bardzo niskiej temperaturze i wysokiej próżni, rozwiązania tego typu znajdują zastosowanie w technologiach kosmicznych. Obecnie można zaobserwować bardzo dynamiczny rozwój systemów lewitacji magnetycznej i ich systematyczne wykorzystanie w różnych aplikacjach. Zastosowanie zawieszenia magnetycznego poprawia bezpieczeństwo, niezawodność i ekonomię startu i lądowania statku powietrznego. Ponadto zaproponowane rozwiązanie ma znaczenie ze względu na poprawę wskaźników ekologicznych, takich jak emisja szkodliwych czynników do atmosfery oraz hałasu. W dalszej części artykułu omówiono prace badawczo-konstrukcyjne zrealizowane w ramach projektu GABRIEL, które mają na celu opracowanie systemu startu i lądowania wykorzystującego układ zawieszeń magnetycznych do utrzymywania statku powietrznego na torze.
\end{abstract}

Słowa kluczowe: zawieszenia magnetyczne, napędy lotnicze, bezpieczeństwo, ekologia

\section{Wprowadzenie}

Jednym z podstawowych manewrów, które wykonuje statek powietrzny, to start i lądowanie. Procedura startu i lądowania jest uzależniona od klasy i typu statku powietrznego. Większość statków powietrznych wykorzystuje drogi startowe do uzyskania prędkości, która zapewnia siłę nośną, lub do wytracania prędkości podczas lądowania. Z dróg startowych korzystają samoloty komunikacyjne, wojskowe oraz lotnictwo dyspozycyjne general aviation. Drogi startowe wykorzystują załogowe i bezzałogowe statki powietrzne. W przypadku lotnictwa pokładowego wykorzystuje się systemy wspomagające start i lądowanie.

\footnotetext{
${ }^{1}$ Autor do korespondencji/corresponding author: Krzysztof Falkowski, Wojskowa Akademia Techniczna, ul. S. Kaliskiego 2, 00-908 Warszawa, tel.: (22) 6939858, e-mail: krzysztof.falkowski@wat.edu.pl

${ }^{2}$ Krzysztof Sibilski, Politechnika Wrocławska, Wybrzeże Wyspiańskiego 27, 50-370 Wrocław, e-mail: krzysztof.sibilski@pwr.wroc.pl
} 
System taki obejmuje katapultę wyrzucającą samolot, natomiast podczas lądowania używa się systemu lin hamujących. Lotnictwo morskie jest wyposażone również $\mathrm{w}$ specjalne statki powietrzne umożliwiające skrócony lub pionowy start i lądowanie (VTOL). Małe samoloty bezzałogowe startują „Z ręki”. W przypadku większych samolotów wykorzystuje się różnego typu wyrzutnie (pneumatyczne, gumowe, prochowe itp.). Lądowanie tego typu statków powietrznych może być realizowane na wiele sposobów (lądowanie w przygodnym terenie, wykorzystanie spadochronów, siatek przechwytujących itp.). Praktycznie mechanizmy i procedury startu oraz lądowania nie zmieniły się od wielu lat. Jednak gwałtowny wzrost ruchu lotniczego oraz względy ekonomiczne i ekologiczne prowadzą do poszukiwania nowych rozwiązań technicznych i procedur startu oraz lądowania. Poszukiwania obejmują systemy dla samolotów liniowych klasy Airbus A320 oraz samolotów bezzałogowych [1].

Obecnie są prowadzone prace badawcze w ramach projektu GABRIEL, które mają na celu opracowanie systemu startu i lądowania wykorzystującego układ zawieszeń magnetycznych do utrzymywania statku powietrznego na torze. W konstrukcji systemu startu i lądowania został wyeliminowany kontakt między torem a statkiem powietrznym, co prowadzi do zmiany procedur startowych, które charakteryzują się lepszymi właściwościami dynamicznymi i poprawiają znacznie wskaźniki ekonomiczne i ekologiczne w eksploatacji statków powietrznych.

\section{Koncepcja systemu startu i lądowania wykorzystująca zawieszenia magnetyczne}

System startu i lądowania jest zbudowany z toru, na którym jest umieszczony specjalny wózek z saniami (rys. 1.). Samolot przed startem znajduje się na wózku. Następnie samolot wraz z wózkiem jest umieszczany na saniach magnetycznych. Do rozpędzania sań jest wykorzystywany liniowy silnik elektryczny. Po uzyskaniu prędkości startowej następuje oddzielenie samolotu od wózka. Samolot przechodzi w zakres wznoszenia, natomiast sanie wraz z wózkiem hamują. Po zatrzymaniu sań następuje rozdzielenie z wózkiem. Sanie powracają do pozycji startowej lub przygotowują się do przyjęcia lądującego samolotu. Podczas lądowania (rys. 2.) procedura odbywa się w odwrotnej kolejności. Po osiągnięciu pozycji decyzyjnej na ścieżce schodzenia (kurs i wysokość) jest uruchamiany system lądowania. Sanie z wózkiem rozpędzają się, a po uzyskaniu odpowiedniej prędkości następuje synchronizacja prędkości sań i samolotu. $\mathrm{Na}$ saniach znajduje się wózek, którego zadaniem jest przechwycenie lądującego samolotu. Po synchronizacji prędkości samolotu i sań samolot wyrównuje, a następnie osiada na wózku. System wchodzi w zakres hamowania, sanie wytracają energię i po zatrzymaniu samolot wraz z wózkiem zjeżdżają na miejsce postojowe. System przygotowuje się do kolejnego startu lub lądowania. Zastosowanie takiego rozwiązania wiąże się ze znacznymi korzyściami ekonomicz- 
nymi, ponieważ start tego typu pozwala zaoszczędzić paliwo, które można wykorzystać podczas lotu (zwiększenie zasięgu). Dodatkowym atutem jest prosta konstrukcja samolotu, niezbędny jest tylko system cumowania do wózka, natomiast jest wyeliminowany układ podwozia wraz z instalacjami wymaganymi do jego sterowania i kontroli pracy [1].

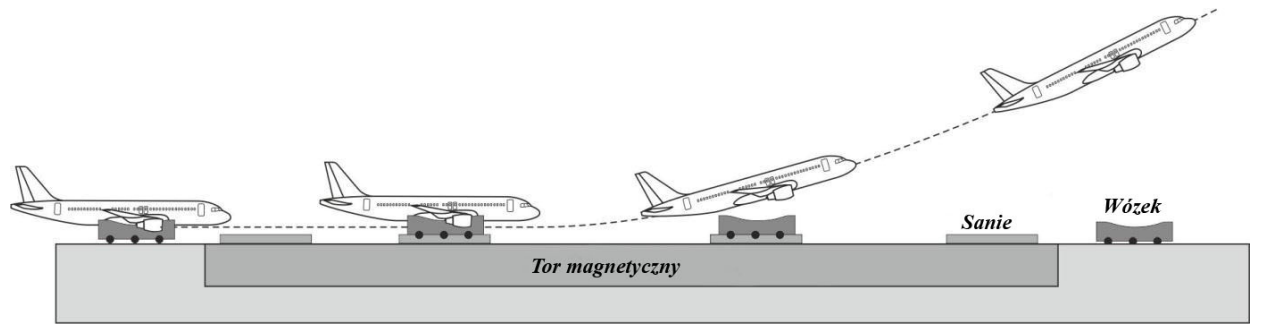

Rys. 1. System startu GABRIEL

Fig. 1. The take-off GABRIEL system

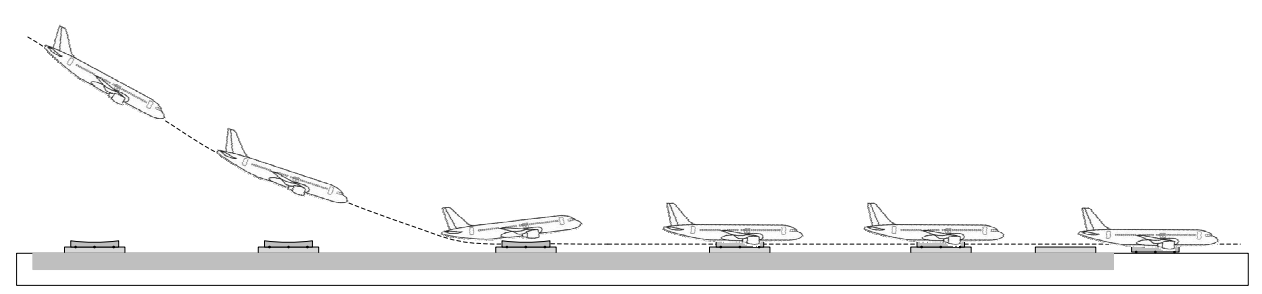

Rys. 2. System lądowania GABRIEL

Fig. 2. The landing GABRIEL system

Kolejnym problemem jest emisja hałasu i zanieczyszczeń, które dostają się na małej wysokości do atmosfery. Obecnie ekolodzy są stosunkowo „łaskawi” dla lotnictwa. Jednak coraz częściej pojawiają się pytania dotyczące emisji szkodliwych czynników do atmosfery przez statki powietrzne. Dlatego każde ograniczenie emisji szkodliwych czynników i zastąpienie jej energią elektryczną jest działaniem proekologicznym. Energia elektryczna obecnie jest zaliczana do zielonej energii. Dodatkowym czynnikiem jest poprawa bezpieczeństwa w zakresie wykonywania manewru startu i lądowania oraz ruchu statków powietrznych w porcie lotniczym [1].

\section{Systemy zawieszeń magnetycznych w projekcie GABRIEL}

Jednym z podstawowych elementów systemu jest układ zawieszeń magnetycznych zapewniających lewitację magnetyczną sań nad torem. Dokonując 
wyboru systemu zawieszeń magnetycznych, kierowano się względami ekonomicznymi i funkcjonalnymi. Zawieszenia magnetyczne dzielą się na aktywne i pasywne. Ze względu na złożoną konstrukcję i koszt zrezygnowano z aktywnych zawieszeń magnetycznych. Do dalszej realizacji zostały wybrane zawieszenia pasywne elektrodynamiczne i wykorzystujące nadprzewodniki. Zawieszenia elektrodynamiczne do generowania sił lewitacji magnetycznej wykorzystują siły oddziaływania magnetycznego między zewnętrznym polem magnetycznym i prądem indukowanym w przewodniku. Źródłem pola magnetycznego są magnesy, które przemieszczając się nad materiałem przewodzącym, indukują w nim prądy. W przypadku zawieszenia pasywnego z nadprzewodnikami wykorzystuje się efekt Meissnera, który występuje podczas wprowadzania nadprzewodnika w temperaturę poniżej krytycznej.

\section{Zawieszenia elektrodynamiczne}

Zawieszenia elektrodynamiczne charakteryzują się bardzo dużą siłą nośną oraz bardzo prostą konstrukcją. Zawieszenie tego typu jest zbudowane z toru, na którym jest umieszczony materiał przewodzący (miedziane płytki - rys. 3.). Na ramie są umieszczone cztery podpory (rys. 3.). Podpora jest zbudowana z zespołów tablic Halbacha, które są rozmieszczone różnicowo. Jak można zauważyć, sanie są wyposażone w koła, które pełnią funkcje spoczynkowe oraz zapewniają wstępne ustawienie szczelin powietrznych magnesów dla małych prędkości. Koła są niezbędne, ponieważ lewitacja w tego typu zawieszeniach występuje po przekroczeniu określonej prędkości przez sanie. Dla małej prędkości sanie poruszają się po torze na kołach. W torach przeznaczonych do przenoszenia dużych statków powietrznych stosuje się taśmy miedziane z perforacją (rys. 4.). Źródłem pola magnetycznego są tablice Halbacha złożone z magnesów sześciennych. Magnesy połączone są tak, aby uzyskać silne pole magnetyczne w określonym kierunku. Przykładowa tablica jest przedstawiona na rys. 5. W wyniku połączenia magnesów można otrzymać sinusoidalną zmianę indukcji magnetycznej o długości zależnej od wymiarów magnesów. Długość fali dla tablicy z rys. 5. wynosi $208 \mathrm{~mm}$. Przesuwająca się nad torem tablica przemagnesowuje tor z częstotliwością, która jest równa stosunkowi prędkości i długości fali.

Przemagnesowanie toru indukuje prąd w jego powierzchni (rys. 6a). Zastosowanie perforacji $\mathrm{w}$ blachach prowadzi do ukierunkowania prądu $\mathrm{w}$ torze. Przepływający prąd posiada składową $I_{y}$, która jest odpowiedzialna za generowanie siły nośnej zawieszenia. Perforacja ogranicza indukowanie prądów wirowych. Na rysunku $6 \mathrm{~b}$ przedstawiono siłę nośną $F_{z}$ i siłę oporu $F_{x}$. Dodatkowo zaznaczono siłę boczną $F_{y}$, która może prowadzić do zsuwania się sań $\mathrm{z}$ toru. Jednak wartość składowej siły $F_{y}$ jest pomijalnie mała. Należy zauważyć, że maksymalne wartości siły nośnej osiągnięto powyżej $20 \mathrm{~m} / \mathrm{s}$. Z przeprowadzonych analiz wynika, że zawieszenia elektrodynamiczne nadają się do użycia przy prędkościach powyżej $5 \mathrm{~m} / \mathrm{s}$. Takie ograniczenie eliminuje zastosowanie 
tego typu sytemu zawieszeń podczas startu i lądowania małych samolotów bezzałogowych.

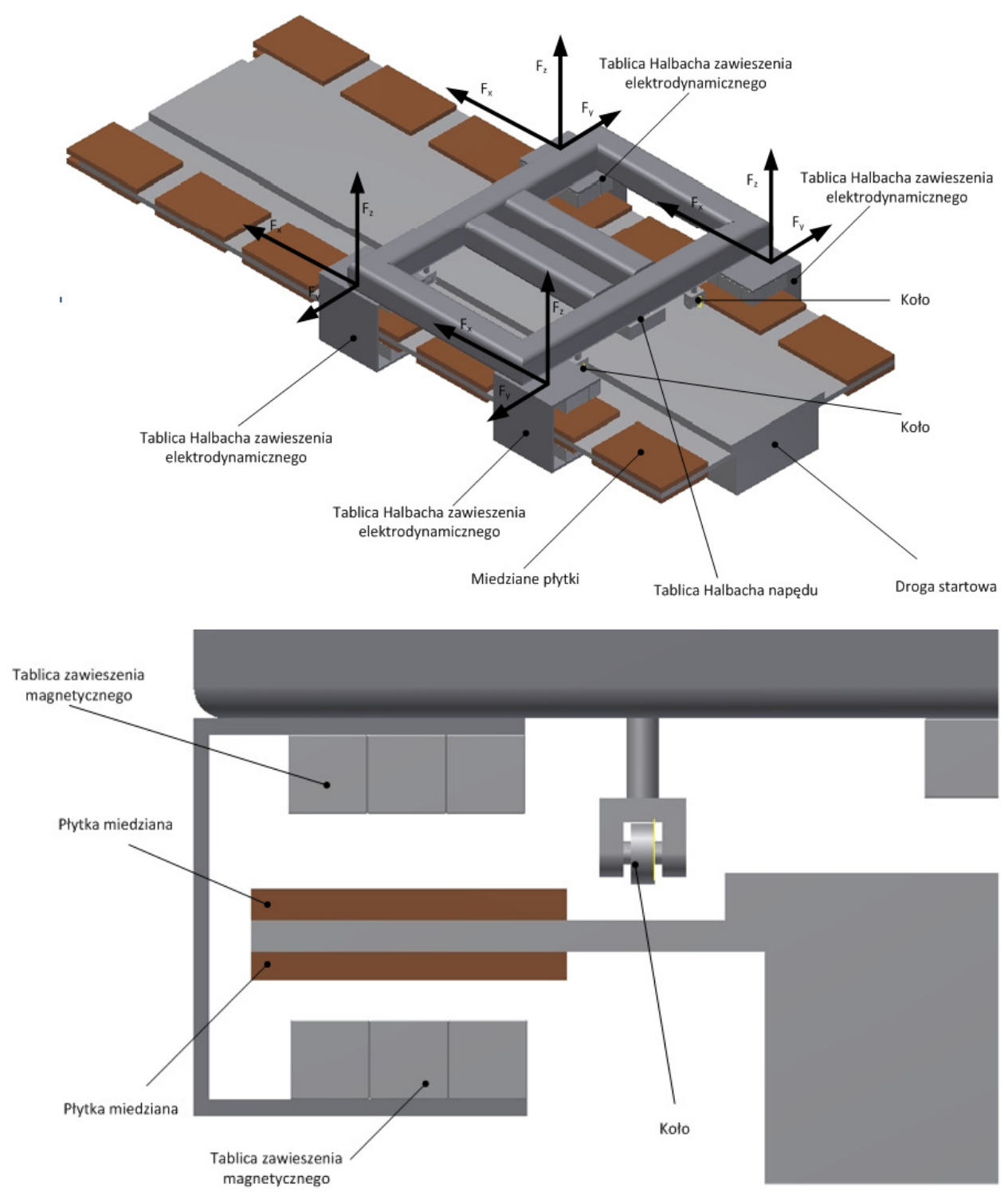

Rys. 3. Koncepcja elektrodynamicznego zawieszenia magnetycznego dla bezzałogowych statków powietrznych

Fig. 3. The conception of electrodynamic magnetic suspension for pilotless aircraft 
a)

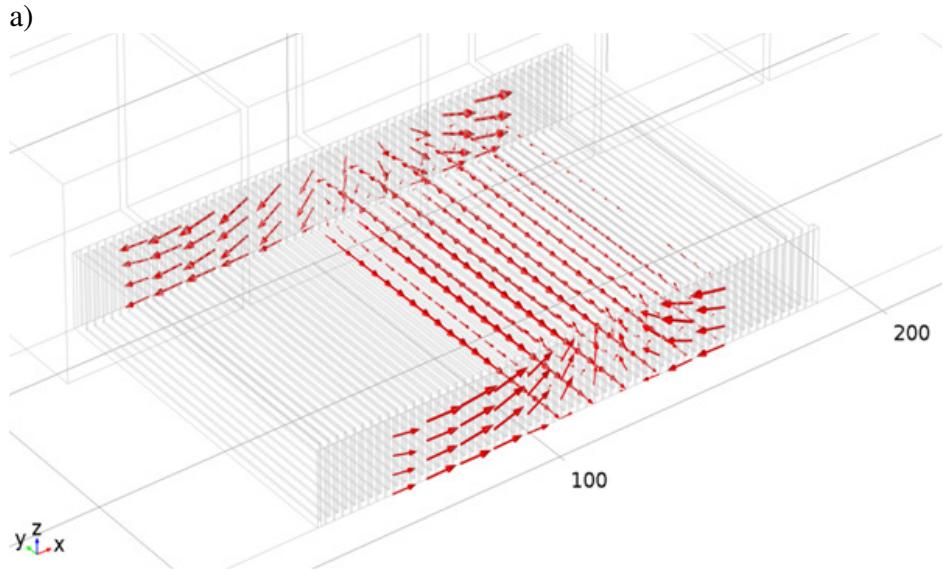

b)

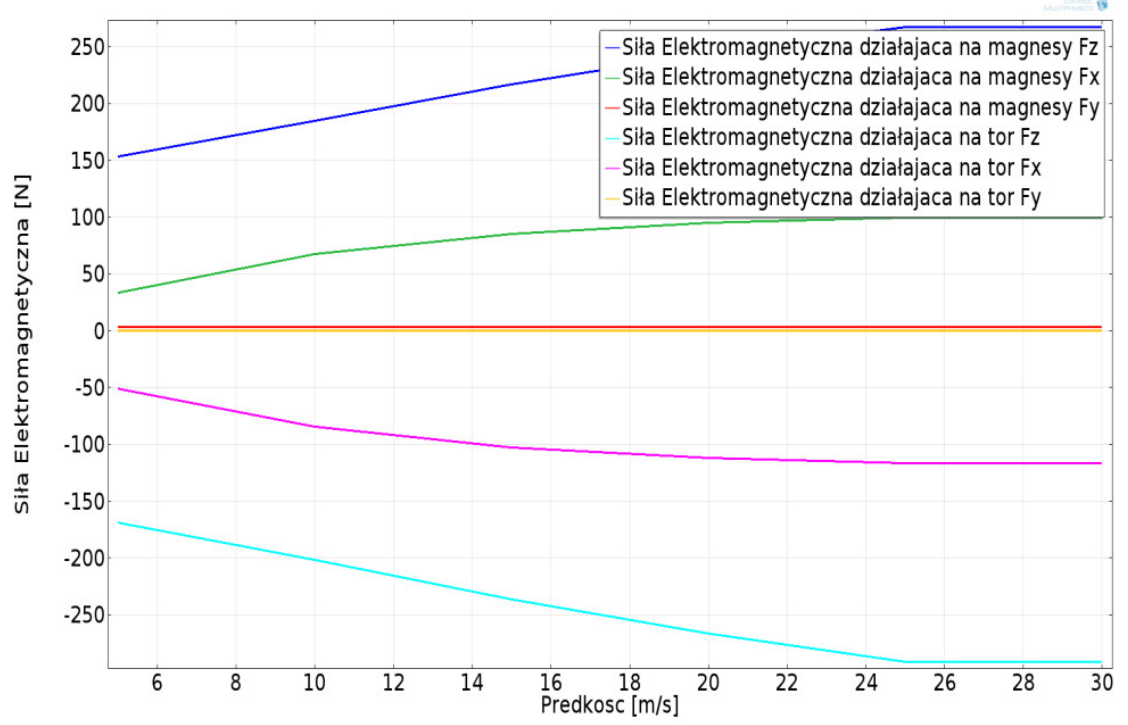

Rys. 4. Prąd indukowany przez tablicę Halbacha w torze (a) oraz siła magnetyczna nośna $F_{z}$ i oporu $F_{x}$ wyznaczona w funkcji prędkości sań (b)

Fig. 4. The current induced by Halbac's array in track (a) and magnetic lift $F_{z}$ and resistance $F_{x}$ forces determined as a function of sledge velocity (b)

\section{Zawieszenia z nadprzewodnikami}

Wady tej jest pozbawiony system zawieszeń magnetycznych z nadprzewodnikami. Ten typ zawieszenia pasywnego pozwala uzyskać stabilną lewitację magnetyczną dla zerowej prędkości liniowej. Zawieszenie takie jest zbudowane z toru, na którym są umieszczone dwie bieżnie. Nad bieżniami znajduje się rama z zamontowanymi podporami. Pojedyncza podpora to pojemnik wykonany 
z aluminium, w którym jest umieszczona ceramika nadprzewodząca YBCO. Wybrany materiał charakteryzuje się temperaturą krytyczną $T_{c}=92 \mathrm{~K}$, co umożliwia poprawną pracę podpory przy zatopieniu nadprzewodnika w ciekłym azocie. Pojemnik, w którym jest umieszczony nadprzewodnik, musi zachowywać szczelność, zapewniać łatwe uzupełnianie ciekłego azotu oraz umożliwiać odparowanie azotu. Dodatkowo pojemniki są izolowane warstwą styropianu [2].

Pasywne zawieszenie magnetyczne $\mathrm{z}$ nadprzewodnikami wykorzystuje efekt Meissnera. Materiał nadprzewodzący po schłodzeniu poniżej temperatury krytycznej generuje silne prądy powierzchniowe, które działają jak ekran wypierający pole magnetyczne $\mathrm{z}$ nadprzewodnika. Cechą charakterystyczną nadprzewodnika jest wektor magnetyzacji, który w nadprzewodniku zawsze ustawia się przeciwnie do linii zewnętrznego pola magnetycznego. Tor magnetyczny jest zbudowany z dwu bieżni. Na każdej bieżni są umieszczone prostopadłościenne magnesy neodymowe $\mathrm{z}$ wektorem magnetyzacji ustawionym pionowo. $\mathrm{W}$ pojedynczej warstwie znajdują się trzy magnesy. Magnesy zewnętrzne mają wektor magnetyzacji o wartości dodatniej, natomiast magnes środkowy posiada wektor magnetyzacji o wartości ujemnej. Na rysunku 5. jest przedstawiony model 3D tablicy zbudowanej z magnesów o takiej orientacji wektorów magnetyzacji. Tak zbudowana tablica magnesów wytwarza silne pole magnetyczne w obszarze styku ich ścian. Pełne omówienie zjawiska koncentracji pola magnetycznego wykracza poza ramy artykułu.

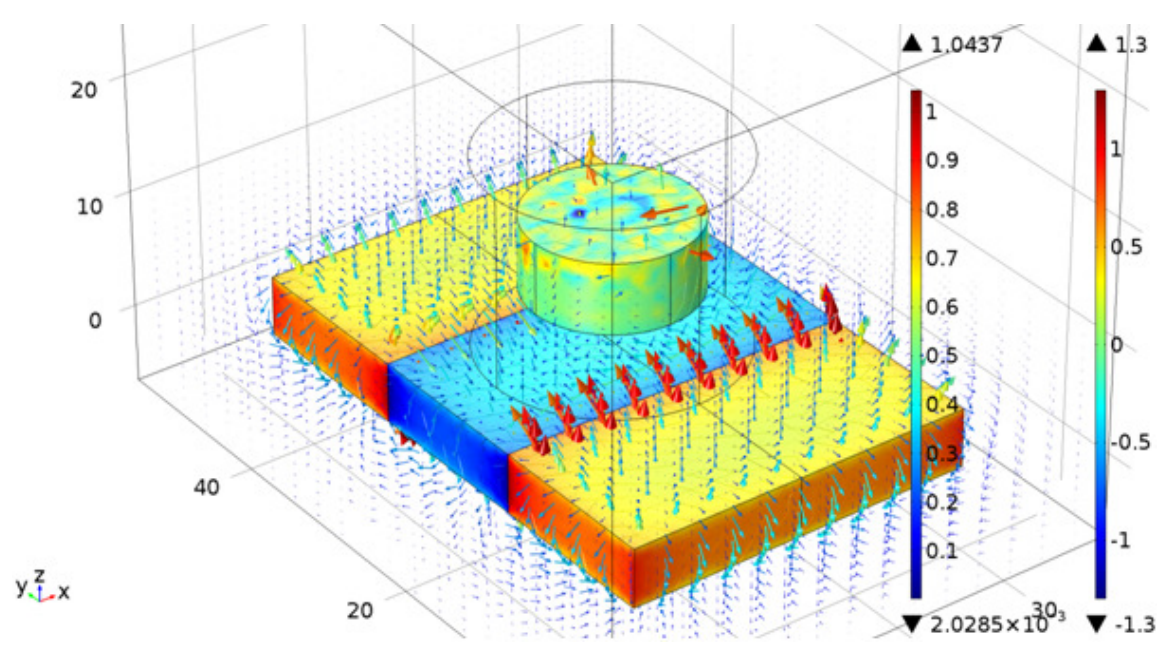

Rys. 5. Model 3D materiał nadprzewodzącego umieszczonego nad tablicą magnesów neodymowych

Fig. 5. 3D model of superconductive material located over the table of neodymium magnet

Na rysunku 6. przedstawiono rozkład pola magnesu w obszarze styku magnesów. W pole jest wprowadzony materiał nadprzewodzący, który powoduje 
zagięcie linii pola magnetycznego. Na rysunku 6a pokazano efekt Meissnera, natomiast na rys. $6 \mathrm{~b}$ indukcję magnetyczną przedstawiono jako wysokość. W obszarze nadprzewodnika indukcja magnetyczna wręcz jest „wycinana” i sprowadzana do wartości zerowych. Na rysunku 7. przedstawiono zmianę siły lewitacji magnetycznej przy oscylacyjnym ruchu nadprzewodnika. Siła została wyznaczona w funkcji zmiany czasu (rys. 7a) i położenia (rys. 7b - przemieszczenie w szczelinie powietrznej nadprzewodnika). Dla pojedynczej kostki YBCO uzyskano siłę magnetyczną o wartości średniej $6 \mathrm{~N}$.

a)

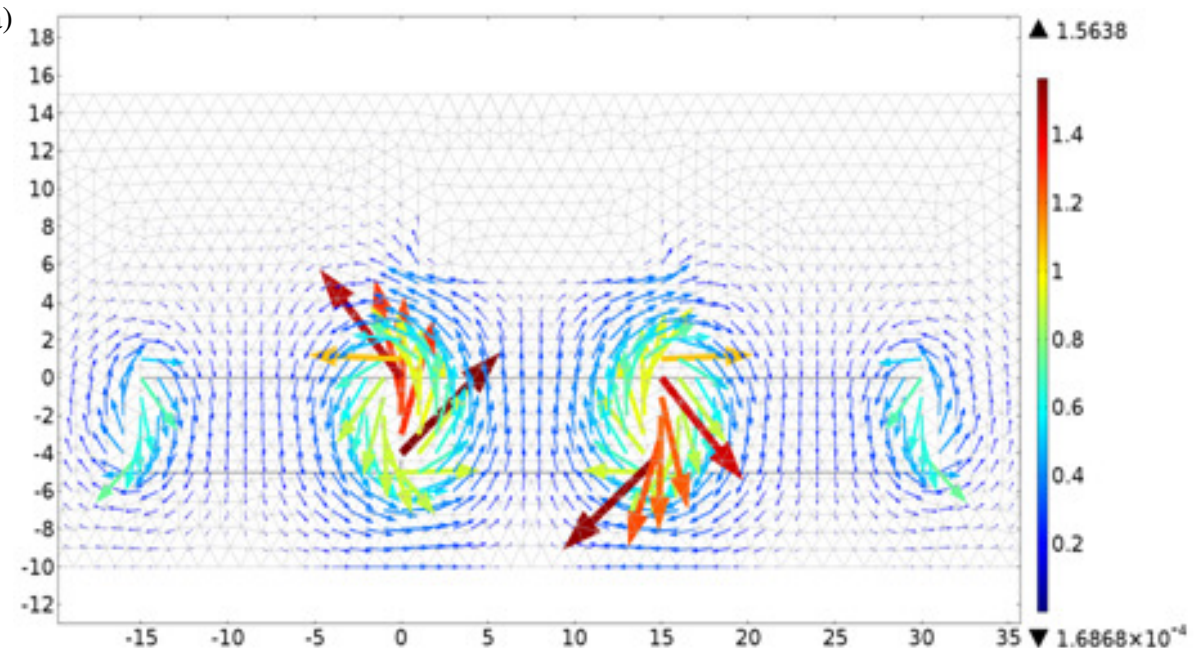

b)

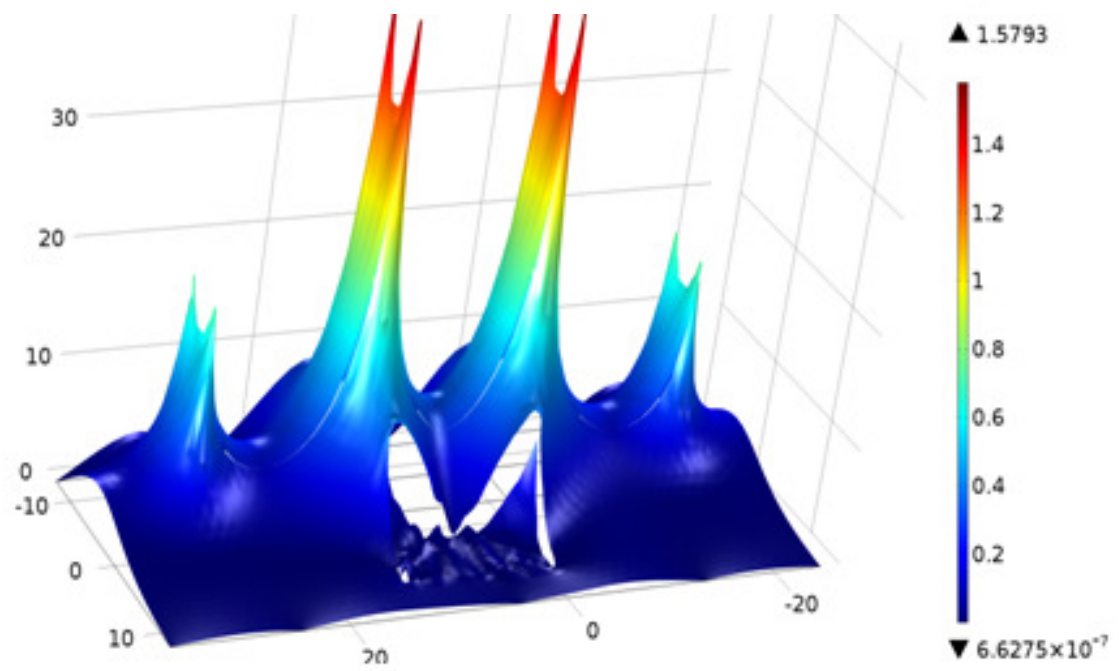

Rys. 6. Nadprzewodnik w polu magnetycznym - efekt Meissnera

Fig. 6. Superconductor in magnetic field - Meissner effect 
a)

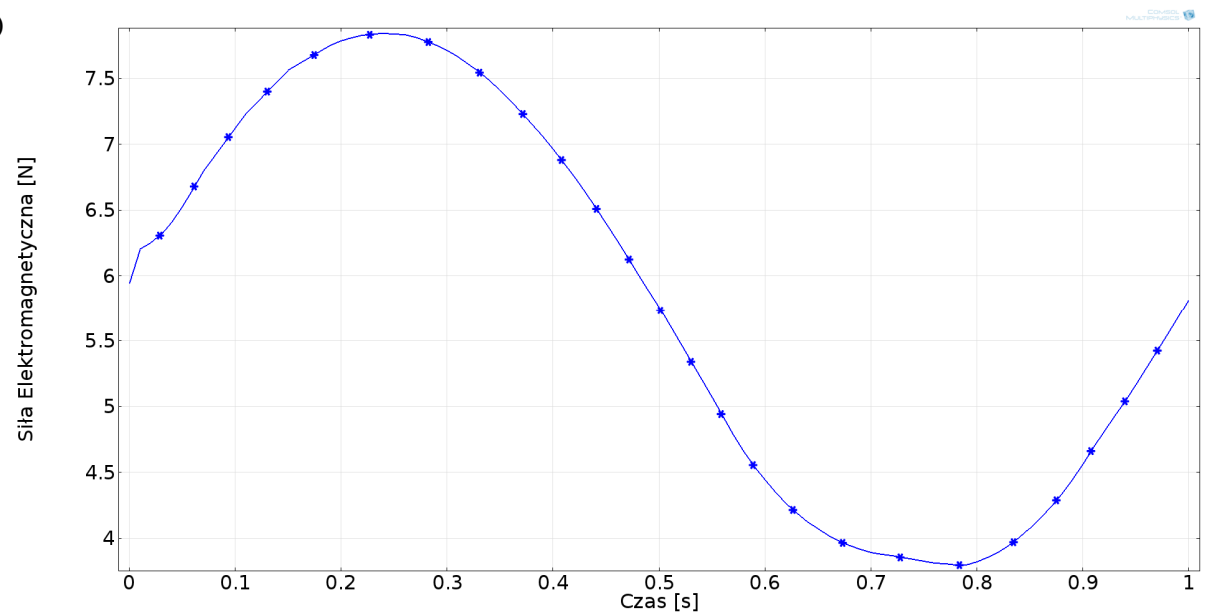

b)

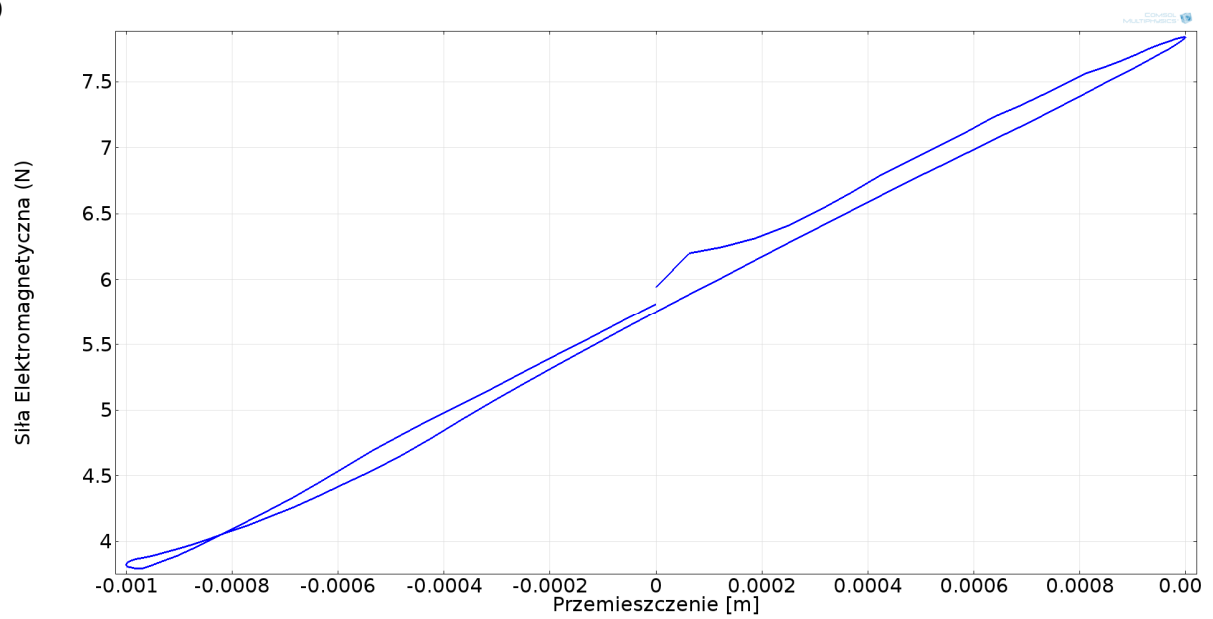

Rys. 7. Zmiana siły magnetycznej przy oscylacyjnym ruchu nadprzewodnika w funkcji czasu (a) oraz położenia (b)

Fig. 7. The variation of magnetic force during oscillatory motion of superconductive as a function of time (a) and position (b)

\section{Podsumowanie}

W pracy przedstawiono system startu i lądowania wykorzystujący zawieszenia magnetyczne. System ten jest propozycją, która ma na celu ograniczenie emisji szkodliwych czynników, zwiększenie bezpieczeństwa i poprawę aspektów ekonomicznych w lotnictwie. Prowadzone prace obejmują dwa kierunki. Jednym $\mathrm{z}$ nich są prace mające na celu zbudowanie system startu dla dużych samolotów rejsowych (np. Airbus A320), drugi to prace nad zbudowaniem sytemu dla bezzałogowych statków powietrznych. Obecnie są prowadzone bardzo 
zaawansowane prace nad zbudowaniem takich systemów startu i lądowania dla UAV klasy micro. W związku z tym realizowany projekt przewiduje zastosowanie zawieszeń magnetycznych z nadprzewodnikami. Projektowany tor jest zbudowany z sekcji o całkowitej długości około $11 \mathrm{~m}$ i przeznaczony dla UAV startujących i lądujących z prędkością do $2,5 \mathrm{~m} / \mathrm{s}$ o masie całkowitej do $2 \mathrm{~kg}$. Projekt ten jest na etapie wykonania stanowisk do testowania i badania siły nośności w układzie z nadprzewodnikami [3]. Proponowane rozwiązanie może być wykorzystane w systemach startu pojazdów kosmicznych. Prace takie są prowadzone przez różne ośrodki naukowe, jednak nie obejmuje ich projekt GABRIEL.

\title{
Literatura
}

[1] Majka A.: Analysis of the required thrust of an aircraft aided during take-off and landing by ground-based system using magnetic levitation technology. 51st AIAA Aerospace Sciences Meeting including the New Horizons Forum and Aerospace Exposition, Grapevine (Dallas/Ft. Worth Region), Texas 2013.

[2] Sibilski K., Falkowski K.: Modelowanie i symulacja lewitacyjnego zawieszenia wózka startowego katapulty samolotu typu „Indutruck”. 52 Sympozjum Modelowanie w Mechanice, Ustroń 2013.

[3] Sibilski K., Falkowski K.: Projekt układu startu i lądowania bezzałogowego statku powietrznego z wykorzystaniem lewitacji magnetycznej. 52 Sympozjum ,Modelowanie w Mechanice", Ustroń 2013.

\section{TAKE-OFF AND LANDING SYSTEM WITH MAGNETIC SUSPENSION - PROJECT GABRIEL}

\begin{abstract}
In the article the conception of tafe-off and landing system using the system of magnetic suspensions has been presented. Due to really good functional properties of magnetic suspensions operating at very low temperatures and high vacuum, for example, solutions such are widely applied in the space technology. Nowadays, the dynamic expansion of magnetic levitation systems and their systematic utilization in different applications can be noticed. The use of magnetic suspension guarantees improvement of safety, reliability and economy of take-off and landing of aircraft. Furthermore, proposed solution improves ecological indicators such as the emission of harmful environmental pollutants and noise. In the next part of article engineering and scientific works made within the framework of the GABRIEL project are presented, which the aim is to develop take-off and landing system utilizing magnetic suspension system keeping the course of aircraft.
\end{abstract}

Keywords: magnetic suspensions, aircraft propulsions, safety, ecology

DOI:10.7862/rm.2013.23

Otrzymano/received: 15.09.2013

Zaakceptowano/accepted: 22.10 .2013 